\title{
5. 下咽頭・頸部食道がんにおける非開胸食道全摘と胃挙上再建法
}

松 浦 鎮 (群馬県立がんセンター・頭頉部)

目 的

頭頸部がんのうちで予後の極めてふるわない下咽頭・ 頸部食道がんの治療成績向上をはかるため, 根治手術に おいて非開胸食道全摘と胃挙上再建法を実施してきたの で，その有用性を明らかにすることを狙いとする。

\section{方 法}

過去11年間（1976-1986年）に下咽頭・頸部食道がん 29 症例に対し, 根治治療を目標として, 咽頭, 喉頭, 全 食道摘出術が実施された。

本手術に当っては, 同時に消化器外科チームの協力を 得て, 非開胸により食道の全抜去とともに, 一期的に後 縱隔経由の胃举上による食道再建術が実施されたもので ある(いわゅる Blunt dissection) (図 1)。原則として 条件が許される限り頸部廓清術も併用された。

本方式で根治手術がなされた症例の予後, 経口摂食ま での期間, その他につき, 従来からおこなわれてきた咽 頭, 喉頭, 食道摘出術後, 局所皮弁により二期的に食道 が再建された症例とにつき比較検討した。

結 果

1）過去15年間の下咽頭・頸部食道がん全症例は計 108例である（表 1)。その治療法比率は, 根治手術とし て咽頭, 喉頭摘出術ないしは, これに食道摘出術を加

表 1-(1) 下咽頭・頸部食道がん 108 例

(1973 1986)

\begin{tabular}{|c|c|c|c|c|c|}
\hline & $\mathrm{N}_{0}$ & $\mathrm{~N}_{1}$ & $\mathrm{~N}_{2}$ & $\mathrm{~N}_{3}$ & 計 \\
\hline $\mathrm{T}_{1}$ & 2 & 2 & & 1 & 5 \\
\hline $\mathrm{T}_{2}$ & 13 & 6 & & 5 & 24 \\
\hline $\mathrm{T}_{3}$ & 22 & 9 & 1 & 25 & 57 \\
\hline $\mathrm{T}_{4}$ & 14 & 3 & 2 & 3 & 22 \\
\hline 計 & 51 & 20 & 3 & 34 & 108 \\
\hline & $\begin{array}{l}\text { I 期 } \\
\text { III 期 } \\
\text { III 期 } \\
\text { IV 期 }\end{array}$ & $\begin{array}{r}2 \\
13 \\
39 \\
54\end{array}$ & $\left.\begin{array}{r}1.8 \% \\
12.0 \% \\
36.1 \% \\
50.0 \%\end{array}\right\}$ & $\begin{array}{l}13.8 \% \\
86.1 \%\end{array}$ & \\
\hline
\end{tabular}

表 1-(2) 下咽頭・頸部食道がん

\begin{tabular}{|c|c|c|c|}
\hline & 男 & 女 & 計 \\
\hline 下 咽 頭 & 58 & 26 & $84(77.7 \%)$ \\
\hline 頸 部 食 道 & 14 & 10 & 24 (22.296) \\
\hline 計 & 72 & 36 & 108 \\
\hline
\end{tabular}

え，局所皮弁で二期的食道再建されたもの 17例（15.7 \%)，および胃挙上術による一期的再建のもの29例(26.8 \%)であり，その他の62例（57.5\%）はすべて手術不能 例で姑息的治療におわった。

2）治療成績を 5 年累稓生存率でみると，従来からの 二期的再建のものはその成綘は $25.0 \%$ あるが，食道抜 去胃挙上によるそれは $55.1 \%$ とその治療成綆は数字の上 では向上がみられた（表2）。

3）原発巣別とその予後（2 年以上）についてみると 類部食道がんが 9 例中 6 例生存し, とくに本治療法の意 義は大きかった（図2）。

4）本一期的食道再建法では，释口提食開始時期は術 後約 2 週間が標準的であった。これは皮弁による二期的 方法のものより格段と早く，したがって入院期間もいち ビるしく短縮されている。

5）術後合併症では胸水貯溜, 縦隔洞炎などが一時的 に認められたものもあったが重篤なものにはならず改善 がみられた。

6）術後の睘下機能については問題はおこらないが, 時として胃液の逆流についての愁訴ある例がみられたが 時期が経つにつれて逐次解消されてきている。発声機能 については，いわゆる食道発声はできえていなかった。

7）食道粘膜全長には肉眼的に 他部位一の Skip lesion は認められなかばた。

結 論

原発巣が顠部食道にあるものあるいは，下咽頭から類 部食道へ浸潤している症例においては，従来からおこな

表 2-（1）咽喉食摘群 17例の Nによる予後

\begin{tabular}{ccc}
\hline $\mathrm{N}$ & 症例数 & 5 年累積生存率 \\
\hline $\mathrm{N}_{0}$ & 10 & $30.6 \%$ \\
$\mathrm{~N}_{1 \sim 3}$ & 7 & $23.9 \%$ \\
\hline 計 & 17 & $29.2 \%$ \\
\hline
\end{tabular}

表 2-(2) Blunt dissection群29例のNによる予後

\begin{tabular}{ccc}
\hline $\mathrm{N}$ & 症例数 & 5 年累積生存率 \\
\hline $\mathrm{N}_{0}$ & 19 & $63.0 \%$ \\
$\mathrm{~N}_{1-3}$ & 10 & $49.3 \%$ \\
\hline 計 & 29 & $55.1 \%$ \\
\hline
\end{tabular}



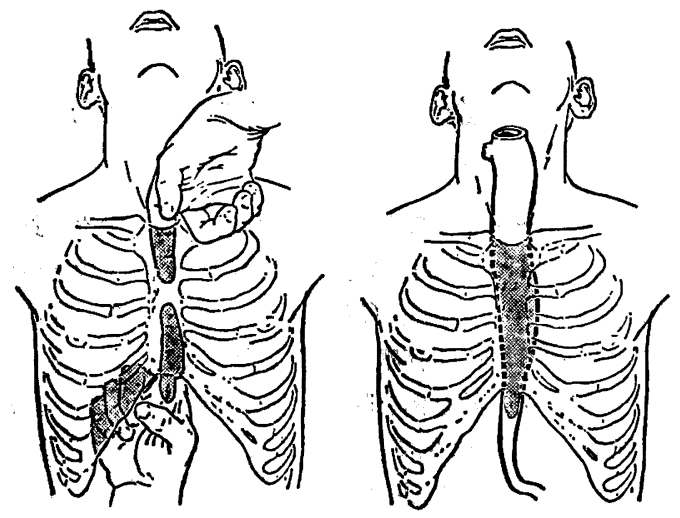

図 1
われている咽喉食摘法ならびに二期的再建法よりも，食 道全抜去による胃挙上による一期的再建法を用いた根治 手術が採用されることに意義があると考えられる。

\begin{tabular}{ll}
\multicolumn{2}{c}{ Blunt dissection 例 29 例 } \\
\hline Pyriformis & 00000000 \\
Postericoid & $00000 / 5$ \\
Posterior wall & $0 / 1$ \\
Ce & $000000006 / 9$ \\
\hline 2年以上 & O生存
\end{tabular}

図 2 